\title{
PENGUATAN PENDIDIKAN KARAKTER SISWA SAAT PANDEMI DI SMP ISLAM RAMAH ANAK
}

\author{
Adam Sugiarto \\ Universitas Pamulang \\ email: dosen1597@unpam.ac.id
}

\begin{abstract}
Abstrak
Penguatan Karakter Siswa (PKS) merupakan proses pembentukan, pembiasaaan dan pengembangan kemampuan siswa dalam berpikir, bersikap dan berperilaku sesuai nilai-nilai Agama yang luhur serta bersesuaian dengan nilai-nilai Pancasila. Pendidikan karakter sangat penting bagi kehidupan manusia, peran pendidikan tidak sekadar menunjukkan pengetahuan moral, tetapi juga menanamkan kecintaan kepada siswa sehingga selalu berupaya untuk melakukan tindakan moral. Penguatan Karakter Siswa (PKS) pada siswa SMP Islam Ramah Anak tidak hanya dilakukan dalam kondisi normal akan tetapi juga dilakukan pada saat terjadi pandemi, dimana para siswa diharuskan belajar dari rumah (BDR). Penguatan Karakter Siswa dilakukan sebagai upaya membentuk dan membiasakan budaya yang baik di lingkungan sekolah dan rumah Sebagai manifestasi dari Program Dinas Pendidikan Kota Depok yang bertema Pekan Penguatan Karakter Siswa (PKKS), yakni membiasakan sikap dan perilaku yang lebih baik seperti mandiri, gotong royong, tanggung jawab, senang membaca, empati dan peduli lingkungan. Dengan harapan, semua siswa mengetahui, memahami dan menerapkan pada setiap aspek kehidupan, dimanapun dan kapanpun berada.
\end{abstract}

Kata kunci: Penguatan Karakter; Pendidikan Karakter; Karakter Siswa

\begin{abstract}
Strengthening Student Character (PKS) is a process of forming, accustoming and developing students' abilities to think, behave and behave according to noble religious values and in accordance with the values of Pancasila. Character education is very important for human life, the role of education is not only to show moral knowledge, but also to instill love for students so that they always try to take moral actions. Strengthening Student Character (PKS) in Islamic Junior High School Ramah Anak students is not only carried out in normal conditions but also during a pandemic, where students are required to learn from home (BDR). Strengthening Student Character is carried out as an effort to form and familiarize a good culture in the school and home environment as a manifestation of the Depok City Education Office Program with the theme of Student Character Strengthening Week (PKKS), which is to get better attitudes and behaviors such as independence, mutual cooperation, responsibility. responsible, happy to read, empathetic and caring for the environment. With hope, all students know, understand and apply to every aspect of life, wherever and whenever they are.
\end{abstract}

Keywords: Character Strengthening; Character Education; Student Character.

\section{PENDAHULUAN}

Satu tahun sudah dunia dihadapkan dengan Wabah Corona Virus Disease (COVID 19) atau lebih dikenal di Indoenesia dengan Virus Corona. Wabah Covid 19 di Indonesia telah meluas ke berbagai wilayah dan memakan banyak korban jiwa. Pemerintah mengambil kebijakan untuk mengurangi dan memutus mata rantai penyebaran virus tersebut dengan memberlakukan physical distancing dan beberapa daerah memberlakukan Pembatasan Sosial Berskala Besar (PSBB). Kebijakan physical distancing dan pemberlakukan Pembatasan Sosial Berskala Besar (PSBB) berdampak kepada seluruh sektor kehidupan termasuk sektor pendidikan. Pemerintah melalui Menteri Pendidikan dan Kebudayaan, Nadiem Anwar Makarim memutuskan untuk memindahkan proses pembelajaran tatap muka menjadi pembelajaran secara daring diiumumkan melalui Surat Edaran Nomor 
36962/MPK.A/HK/2020. Dengan demikian pembelajaran di rumah secara daring diberlakukan pada seluruh tingkatan pendidikan. Meskipun sekolah menerapkan belajar dari rumah, bukan berarti guru hanya memberikan tugas saja kepada peserta didik, tetapi juga ikut berinteraksi dan berkomunikasi membantu peserta didik dalam mengerjakan tugas-tugas mereka. Guru tetap perlu berinteraksi dan berkomunikasi dengan siswanya meskipun tidak dari dalam ruang kelas. Karena kehidupan manusia tidak akan pernah lepas dari pendidikan, baik di dalam keluarga, masyarakat, terlebih lagi di Lembaga Pendidikan formal yaitu sekolah. Dalam UU RI No 20 Tahun 2003 disebutkan bahwa pendidikan nasional berfungsi untuk mengembangkan serta membentuk watak peradaban bangsa yang bermartabat untuk mewujudkan cita-cita bangsa, yaitu mencerdaskan kehidupan berbangsa serta berupaya untuk mengembangkan potensi serta kemampuan peserta didik dan menjadikan mereka menjadi manusia yang beriman, berakhlak mulia, berilmu, cakap, kreatif, mandiri dan menjadi warga negara yang demokratis serta tanggung jawab. Sehingga dalam upaya untuk mewujudkan hal tersebut seluruh lembaga satuan pendidikan yang berada di wilayah Negara Kesatuan Republik Indonesia tanpa terkecuali memiliki peran penting dalam merealisasikan fungsi pendidikan nasional yang terdapat dalam undang-undang tersebut.

Adapun istilah pendidikan karakter baru muncul pada dekade terakhir di Amerika Serikat, termasuk yang dipakai di Indonesia dalam beberapa tahun terakhir. Seperti yang dinyatakan Suyata dalam Darmiyati Zuchdi (ed.2011). dalam sepuluh sampai dua puluh tahun lalu, istilah pendidikan moral lebih populer di Amerika, sedang istilah pendidikan karakter lebih popular di di kawasan Asia. sedangkan di Inggris orang lebih suka menyebutnya dengan istilah pendidikan nilai. Adapun di Indonesia dikenal dengan istilah pendidikan budi pekerti dan pendidikan moral Pancasila.

$$
\text { Upaya menyiapkan kondisi, }
$$

sarana/prasarana, kegiatan, pendidikan, dan kurikulum yang mengarah kepada Strategi pembentukan karakter dan budi pekerti generasi bangsa dilakukan secara menyeluruh dan konsisten. Namun, membantu manusia untuk menjadi cerdas dan pintar (smart) boleh jadi mudah dilakukan akan tetapi menjadikan manusia agar menjadi orang yang baik dan bijak dengan karakter yang baik, tampaknya jauh lebih sulit atau bahkan sangat sulit. hal tersebut disadari atau tidak bahwa saat ini terjadi krisis akhlak yang menerpa semua lapisan masyarakat. termasuk pada anak-anak usia sekolah. Sebagai seorang meyakini bahwa banyaknya Nabi dan Rasul yang diutus oleh Allah SWT kepada umat manusia selain untuk menyeruh kepada penyembahan kepada Allah juga untuk memperbaiki sikap dan perilaku manusia yang menyimpang bahkan dalam sebuah riwayat disebutkan bahwa diutusnya Nabi Muhammad saw oleh Allah SWT semata-mata untuk menyempurnaan akhlak manusia.

Untuk mencegah lebih parahnya krisis akhlak yang terjadi, terutama di kalangan siswa pada saat terjadinya pandemi disebabkan kesalahan dalam menggunakan teknologi yang semakin mudah, Sekolah dituntut untuk memainkan peran dan tanggungjawabnya dalam menanamkan, membiasakan dan mengembangkan nilai-nilai yang baik serta membantu para siswa dalm membentuk dan membangun karakter mereka dengan nilainilai yang baik. Pekan Penguatan Karakter Siswa yang dilakukan diarahkan untuk memberikan tekanan pada nilai-nilai atau karakter-karakter tertentu seperti mandiri, gotong royong, tanggung jawab, senang membaca, empati dan peduli lingkungan, sehingga para siswa dapat melakukan dan membiasakan karakter-karakter tersebut dalam kehidupan mereka sendiri.

Pendidikan karakter yang terdiri dari dua kata yaitu pendidikan dan karakter. Menurut Raden Mas Soewardi Soerjaningrat atau yang lebih dikenal dengan Ki Hadjar Dewantara yang dikutip oleh Henricus Suparlan dalam Jurnal Filsafat, Fakultas Psikologi, Universitas Sarjanawiyata Tamansiswa Tahun 2015 bahwa pendidikan merupakan salah satu usaha pokok untuk memberikan nilai-nilai kebatinan yang ada dalam hidup rakyat yang berkebudayaan kepada tiap-tiap turunan baru (penyerahan 
kultur), tidak hanya berupa pemeliharaan akan tetapi juga dengan maksud memajukan serta memperkembangkan kebudayaan, menuju ke arah keseluruhan hidup kemanusiaan. Kata karakter berasal dari bahasa Yunani charassein, yang berarti to engrave (melukis, menggambar), seperti orang yang melukis pada kertas atau memahat batu. Berakar dari pengertian tersebut karakter kemudian diartikan sebagai tanda atau ciri yang khusus, dan karenanya melahirkan satu pandangan bahwa karakter adalah pola perilaku yang bersifat individual, keadaan moral seseorang. Sedangkan menurut Kamus Besar Bahasa Indonesia Karakter merupakan sifat-sifat kejiwaan, akhlak atau budi pekerti yang membedakan seseorang dari yang lain.

Pendidikan karakter dapat didefinisikan sebagai segala upaya atau usaha yang dapat dilakukan untuk mempengaruhi karakter siswa. Menurut T. Ramli, pendidikan karakter memiliki esensi dan makna yang sama dengan pendidikan moral dan pendidikan akhlak (Kemendiknas, 2010). Dari pengertian tersebut dapat disimpulkan bahwa pendidikan karakter merupakan suatu sistem penerapan nilai-nilai moral pada peserta didik melalui ilmu pengetahuan, pembiasaan dan implementasi nilai-nilai tersebut dalam kehidupan seharihari, baik terhadap diri sendiri, sesama, lingkungan, yang tercermin dalam periku atau akhlak yang baik.

Menurut Lickona yang di kutip oleh Ajat Sudrajat dalam Jurnal Pendidikan Karakter FIS Universitas Negeri Yogyakarta ada tujuh alasan mengapa pendidikan karakter itu harus disampaikan. Ketujuh alasan yang dimaksud adalah sebagai berikut.

1. Cara terbaik untuk menjamin anak-anak (siswa) memiliki kepribadian yang baik dalam kehidupannya.

2. Cara untuk meningkatkan prestasi akademik.

3. Sebagian siswa tidak dapat membentuk karakter yang kuat bagi dirinya di tempat lain.

4. Persiapan siswa untuk menghormati pihak atau orang lain dan dapat hidup dalam masyarakat yang beragam.

5. Berangkat dari akar masalah yang berkaitan dengan problem moral-sosial, seperti ketidaksopanan, ketidakjujuran, kekerasan, pelanggaran kegiatan seksual, dan etos kerja (belajar) yang rendah.

6. Persiapan terbaik untuk menyongsong perilaku di tempat kerja.

7. Pembelajaran nilai-nilai budaya yang merupakan bagian dari kerja peradaban.

Penguatan Pendidikan Karakter (PPK) pada saat terjadinya pandemi sangat penting, mengingat para siswa sangat membutuhkan pendampingan dalam menggunakan gadget, sehingga penguatan pendidikan karakter harus melalui proses pembentukan, trasformasi, trasmisi dan mengembangkan potensi peserta didik agar berpikiran baik, berhati baik, dan berperilaku baik sesuai dengan falsafah hidup Pancasila (Kemendikbud: 2016). Karena sesungguhnya karakter merupakan hasil interaksi antara seseorang dengan lingkungan, sehingga dalam Penguatan Pendidikan Karakter (PPK) yang ditekankan pada pembiaasan dan interaksi seseorang dengan lingkungannya. Oleh karena itu, penelitian ini dimaksudkan untuk mengidentifikasi strategi dan implementasi pelaksanaan pendidikan karakter di SMP Islam Ramah Anak Depok.

\section{METODOLOGI}

Jenis penelitian ini adalah penelitian deskriptif kualitatif untuk mengetahui penguatan pendidikan karakter siswa saat pendemi yang sudah dilakukan di SMP Islam Ramah Anak Depok. Subjek penelitian ini adalah kepala sekolah, siswa, guru dan orangtua. Teknik pengumpulan data yang digunakan dalam penelitian ini adalah wawancara, observasi, dan dokumentasi. Wawancara digunakan untuk menjaring data atau informasi yang berkaitan dengan berbagai kebijakan yang dilakukan sekolah dalam pelaksanaan pendidikan karakter dan kegiatan siswa selama dirumah dalam mengimplementaiskan pendidikan karakter. Observasi dilakukan untuk melihat implementasi pendidikan karakter melalui pembelajaran secara online. Teknik dokumentasi digunakan untuk memperoleh data tentang tata tertib sekolah dan rencana pembelajaran yang yang mendukung penguatan karakter siswa yang dibuat oleh 
guru. Untuk memperoleh data yang dapat dipertanggungjawabkan secara ilmiah, dalam penelitian ini dilakukan pemeriksaan keabsahan data. Dalam penelitian ini teknik pemeriksaan keabsahan data yang digunakan adalah teknik triangulasi, yaitu teknik penyilangan informasi yang diperoleh dari sumber sehingga pada akhirnya

hanya data yang absah saja yang digunakan untuk mencapai hasil penelitian (Arikunto, 2006:18). Teknik triangulasi dilakukan dengan cara triangulasi metode, yaitu dengan mengecek ulang informasi hasil wawancara dengan dokumentasi dan observasi.

\section{HASIL DAN PEMBAHASAN}

Pendidikan karakter dapat diimplemetasikan melalui beberapa strategi dan pendekatan yang meliputi: (1) pengintegrasian nilai dan etika pada mata pelajaran; (2) internalisasi nilai positif yang di tanamkan oleh semua warga sekolah (kepala sekolah, guru, dan orang tua); (3) pembiasaan dan latihan; (4) pemberian contoh dan teladan; (5) penciptaan suasana berkarakter di sekolah; dan (6) pembudayaan. Diantara cara yang dilakukan untuk meningkatkan kesesuaian dan mutu pendidikan karakter, Kementerian Pendidikan Nasional mengembangkan Grand Design pendidikan karakter untuk setiap jalur, jenjang, dan jenis satuan pendidikan. Berdasarkan grand design yang di kembangkan Kemendiknas tahun 2010 secara psikologis dan sosial kultural pembentukan karakter dalam diri individu merupakan fungsi dari seluruh potensi individu manusia (kognitif, afektif, konatif, dan psikomotorik) dalam konteks interaksi sosial kultural (dalam keluarga, sekolah, dan masyarakat) dan berlangsung sepanjang kehidupan manusia. Grand design menjadi rujukan konseptual dan operasional pengembangan, pelaksanaan, dan penilaian pada setiap jalur dan jenjang pendidikan. Konfigurasi karakter dalam konteks totalitas proses psikologis dan sosialkultural tersebut dikelompokan dalam: (1) olah hati (2) olah pikir (3) olah raga dan kinestetik dan (4) olah rasa dan karsa. Keempat proses psikososial tersebut secara terpadu saling berkait yang bermuara pada pembentukan karakter.

Siswa SMP Islam Ramah Anak berjumlah 73 siswa, dengan perincian sebagai berikut.

Tabel 1.

Jumlah Siswa SMP Islam Ramah Anak

\begin{tabular}{|c|c|c|}
\hline No & Kelas & Jumlah Siswa \\
\hline 1 & VII & 16 \\
\hline 2 & VII & 35 \\
\hline 3 & IX & 22 \\
\hline
\end{tabular}

Ket: Data Tahun 2021

Adapun fasilitas kegiatan belajar mengajar yang dimiliki oleh SMP Islam Ramah Anak Depok meliputi: papan tulis (white board), meja, kursi, spidol, tape, video, laptop, komputer, perpustakaan, internet dan proyektor. Fasilitas ini digunakan untuk membantu kelancaran kegiatan belajar mengajar maupun kegiatan sekolah lainnya.

Untuk melakukan penguatan karakter siswa, yang perlu dilakukan adalah menciptakan suasana yang berkarakter (penuh dengan nilai-nilai). Penciptaan suasana yang berkarakter sangat dipengaruhi oleh situasi dan kondisi dan tempat. Pertama, penciptaan budaya berkarakter yang bersifat vertikal (ilahiah). Kegiatan ini diwujudkan dalam bentuk hubungan dengan Allah SWT, Tuhan Yang Maha Esa, melalui peningkatan secara kuantitas maupun kualitas kegiatan-kegiatan keagamaan yang dibiasakan oleh sekolah kepada siswa-siswi SMP Islam Ramah Anak yang bersifat ubudiyah, seperti pebiasaan sholat berjamaah, Sholat Dhuha, puasa Senin dan Kamis, membaca Al-Qur'an, sedekah, kajian PINTER ALIM (Pembinanan Karakter dan bina pribadi islami) dan lain sebagainya.

\section{Al-Hasanah : Jurnal Pendidikan Agama Islam}


Kedua, penciptaan budaya berkarakter yang bersifat horizontal(insaniah). Langkah ini dilakukan dengan menjadikan sekolah sebagai intuisi sosial. Pengembangan karakter di sekolah dilakukan melalui pendekatan pembiasaan, keteladanan, dan pendekatan persuatif.

Pendidikan Karakter merupakan sistem pendidikan yang mengembangkan nilai-nilai karakter pada peserta didik sehingga mereka memiliki nilai-nilai dan karakter serta menerapkan nilai-nilai tersebut dalam kehidupan. Berikut ini merupakan kegiatan penanaman pendidikan karakter di SMP Islam Ramah Anak yang di observasi oleh penulis pada Pekan Penguatan Karakter Siswa (PPKS) yang dilaksanakan di SMP Islam Ramah Anak.

\section{Mandiri}

Menurut Kamus Besar Bahasa Indonesia (KBBI), arti kata mandiri adalah dalam keadaan dapat berdiri sendiri. Arti lainnya dari mandiri adalah tidak bergantung pada orang lain. Memiliki karakter mandiri, berarti memiliki etos kerja yang baik, ketangguhan, daya juang, profesionalitas, kreativitas, dan keberanian. Contoh kegiatan yang dilakukan: 1. Mencuci piring atau gelas setelah makan 2 . Merapikan kamar atau tempat tidur sehingga selalu rapi dan bersih 3. Berusaha mengerjakan tugas-tugas yang diberikan guru tanpa bantuan orang lain.

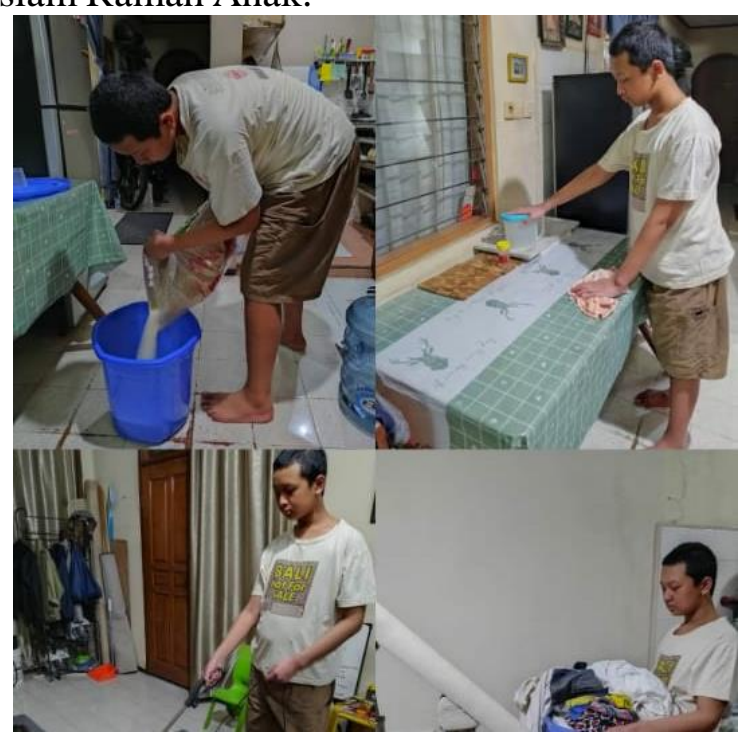

Gambar 1

Pembiasaan Karakter Mandiri

(Sumber Foto: Galeri Foto SMP Islam Ramah Anak)

\section{Gotong Royong}

Berdasarkan Kamus Besar Bahasa Indonesia, gotong royong memiliki arti bekerja bersamasama, tolong menolong, atau bantu-membantu. Contoh kegiatan yang dilakukan: 1. Membantu tetangga membersihkan rumahnya apabila ada acara yang diselenggarakan tetangga 2 . Membersihkan rumah dengan bersama keluarga. 3. Membersihkan selokan dengan masyarakat. 4. Membersihkan dalam atau luar tempat ibadah, contoh nya Masjid. 5. Membersihkan halaman sekolah.

\section{Tanggung Jawab}

Bertanggung jawab dimaksudkan sebagai suatu keadaan di mana semua tindakan atau perbuatan atau sikap merupakan penjelmaan dari nilai-nilai moral serta nilai-nilai kesusilaan. Contoh kegiatan yang dilakukan: 1. Belajar dengan bersungguh-sungguh agar dapat berbakti pada orang tuanya. 2. Seorang kakak yang menjaga adiknya dan menjadi teladan yang baik. 3. Membersihkan sekitar rumah yang menjadi tugasnya 4 . Melaksanakan tugas piket kelas. 


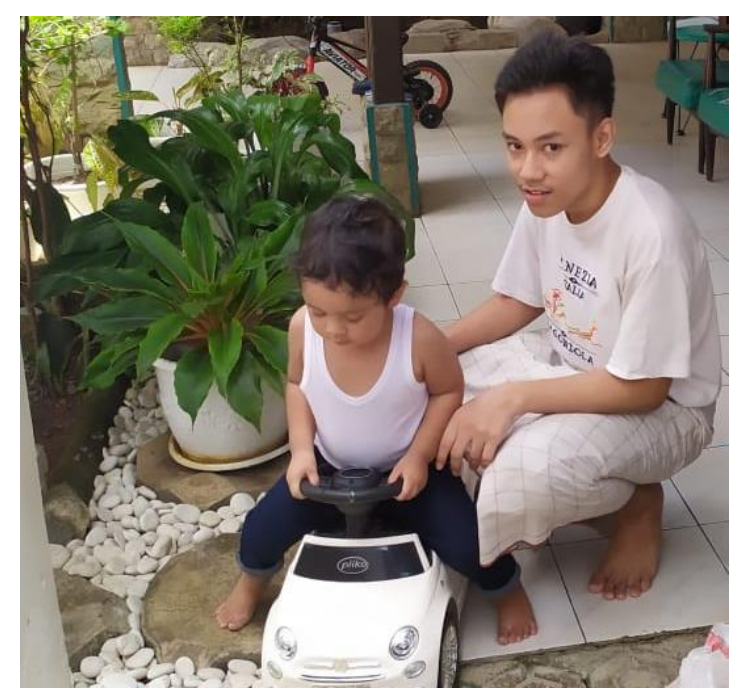

Gambar 2

Pembiasaan Karakter Tanggung Jawab (Sumber Foto: Galeri Foto SMP Islam Ramah Anak)

4. Senang Membaca

Rasa ingin meningkatkan pengetahuan dan pemahaman melalui gemar mencari informasi baru lewat bahan bacaan. Contoh kegiatan

yang dilakukan: Siswa diminta untuk membaca sebuah buku yang bermanfaat (fiksi/non fiksi), kemudian melaporkan resume hasil bacaannya ke sekolah.

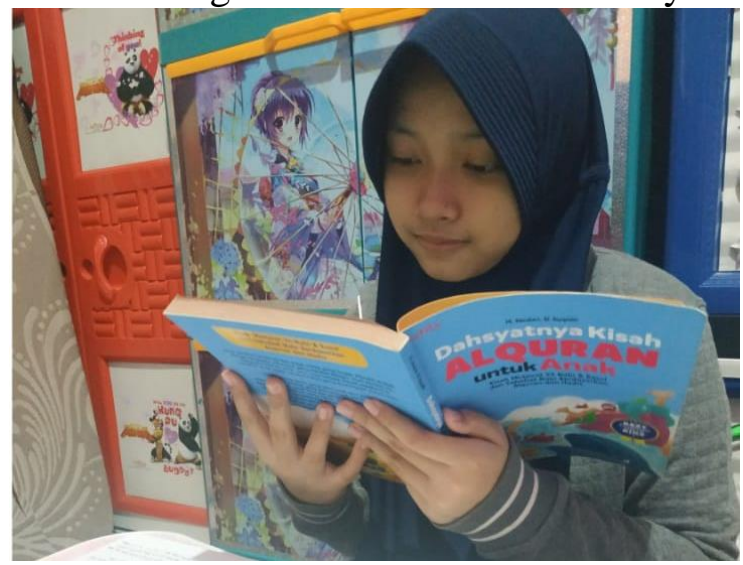

Gambar 3

Pembiasaan Karakter Gemar Membaca

(Sumber Foto: Galeri Foto SMP Islam Ramah Anak)

\section{Empati}

Pengertian empati merupakan kemampuan diri seorang individu untuk berbagi perasaan yang berlandaskan pada rasa peduli. Contoh kegiatan yang dilakukan: 1. Memberikan bantuan dan dukungan kepada orang-orang yang sedang tertimpa musibah, seperti bencana alam. 2. Membagi rejeki yang diperoleh kepada orang-orang di sekitar, terutama yang membutuhkan. 3. Membantu menyeberangkan jalan. 4. Membantu orang yang membawa bawaan yang berat. 5. Menjenguk dan menghibur teman yang sedang sakit. 


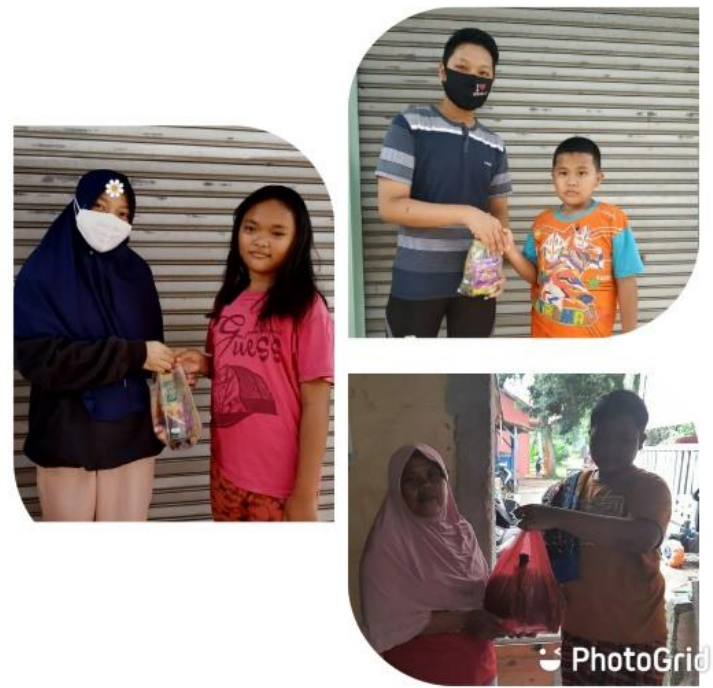

Gambar 4

Pembiasaan Karakter Empati

(Sumber Foto: Galeri Foto SMP Islam Ramah Anak)

6. Peduli Lingkungan

Kegiatan yang dilakukan: 1. Membersihkan sampah yang ada dilingkungan masyarakat 2 .
Menanam pohon 3. Mengumpulkan sampah plastik dan memisahkannya dari sampah organik.

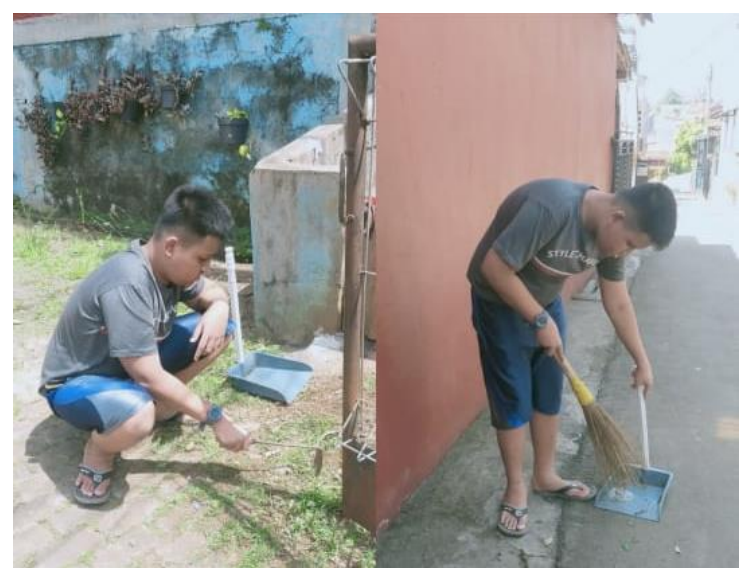

Gambar 5

Pembiasaan Karakter Gemar Membaca

(Sumber Foto: Galeri Foto SMP Islam Ramah Anak)

Pendidikan karakter di SMP Islam Ramah Anak dilaksanakan dalam tiga kelompok kegiatan. pertama, pembentukan karakter yang terpadu dengan pembelajaran pada mata pelajaran. Berbagai hal yang terkait dengan karakter (nilai-nilai, norma, iman dan ketaqwaan, dan lain-lain) dirancang dan diimplementasikan dalam pembelajaran mata pelajaran-mata pelajaran yang terkait, seperti Pendidkan Agama, PPKN, IPS, IPA, PJOK, dan lain-lain. Hal ini dimulai dengan pengenalan nilai secara kognitif, penghayatan nilai secara afektif, akhirnya ke pengamalan nilai secara nyata oleh peserta didik dalam kehidupan sehari-hari. Kedua, pembentukan Karakter yang terpadu dengan manajemen sekolah. Berbagai hal yang terkait dengan karakter (nilai-nilai, norma, iman dan ketaqwaan, dan lain-lain). Ketiga, pembentukan karakter yang terpadu dengan ekstra kurikuler dan program-program 
sekolah. Beberapa kegiatan ekstra kurikuler dan program yang memuat pembentukan karakter antara lain: (1) Pembinaan Tilawah dan tahfizh al-Qur'an (2) pembinaan Bahasa Asing (3) Pendidikan karakter dan bina pribadi islami (4) Sholat berjama'ah, dhuha dan dzikir pagi (5) Qur'an Camp (6) Super Camp. dan lain-lain.

Guru memiliki peranan yang sangat penting dalam melakukan pembiasaan atau pembinaan karakter terhadap siswa dan siswi di SMP Islam Ramah Anak baik melalui pembelajaran yang dipadukan dengan pendidikan karakter maupun melalui pendekatan-pendekatan emosional melalui program-program yang dirancang oleh manajemen sekolah pada saat pandemi diantara program-program tersebut berupa mutaba'ah atau evaluasi kegiatan keagamaan yang dilakukan oleh siswa di rumah seperti shalat 5 waktu dan shalat sunnah lainnya, puasa sunnah dan sedekah jum'at, setiap hari jum'at siswa dan siswi di SMP Islam Ramah Anak diwajibkan untuk membaca surat yasin dan surat al-kahf juga mengikui kajian PINTER ALIM (Pendidikan Karakter Pribadi Muslim) yang diadakan oleh sekolah dengan guru-guru yang menjadi nara sumbernya sebagai penguatan nilai-nilai karakter siswa yang akan dievaluasi setiap pekannya.

\section{PENUTUP}

Berdasarkan uraian dan pembahasan tersebut di atas, dapat dikemukakan beberapa simpulan sebagai berikut. Pertama, strategi Pembentukan dan Pembiasaan karakter siswa pada masa pandemi dapat dilakukan dengan cara yaitu: (1) pengintegrasian nilai dan etika pada mata pelajaran; (2) internalisasi nilai positif yang di tanamkan oleh semua guru dan kepala sekolah (3) pembiasaan dan latihan, pemberian contoh dan teladan; dan (4) penciptaan suasana berkarakter di dimanapun berada. Pendidikan karakter di SMP Islam Ramah Anak dapat dilakukan melalui: (1) keterpaduan antara pembentukan karakter dengan pembelajaran; dan (2) manajemen sekolah dengan program-program yang dapat mendukung penguatan karakter siswa.
Berdasarkan simpulan di atas, dapat diberikan saran-saran sebagai berikut. Pertama, guru sebagai sosok yang memiliki peran penting dalam implementasi pendidikan karakter di sekolah maupun di luar sekolah. Disamping melakukan pembinaan dan pembiasaan terhadap karakter siswa sudah semestinya guru harus memiliki karakter yang baik, memiliki kompetensi kepribadian yang baik, dimana kompetensi kepribadian tersebut menggambarkan sifat pribadi dari seorang guru. Kedua, banyak hal yang dapat dilakukan untuk merealisasikan pendidikan karakter baik di sekolah maupun di rumah. Konsep karakter tidak cukup dijadikan sebagai bagian dari poin penting dalam silabus dan rencana pelaksanaan pembelajaran, namun harus lebih dari itu, dijalankan dan dipraktikkan. Dimulai dengan belajar taat dengan peraturan sekolah. Sekolah harus menjadikan pendidikan karakter sebagai sebuah tatanan nilai yang berkembang dengan baik di sekolah yang diwujudkan dalam contoh dan seruan nyata yang diaplikasikan oleh tenaga pendidik dan kependidikan di sekolah dalam keseharian kegiatan di sekolah.

\section{DAFTAR PUSTAKA}

Arikunto, Suharsimi. (2006) Prosedur Peneli tian Suatu Pendekatan Praktik. Jakarta: Rineka Cipta.

Darmiyati Zuchdi. (2011) Pendidikan Karakter dalam Perspektif Teori dan Praktik. Yogyakarta: UNY Press.

Kemendikbud. (2016) Kajian dan Pedoman Penguatan Pendidikan Karakter. Jakarta: Kementerian Pendidikan dan Kebudayaan Republik Indonesia.

Kemendiknas. (2010) Pembinaan Pendidikan Karakter di Sekolah Menengah Pertama. Jakarta: Departemen Pendidikan Nasional.

Sudrajat, Ajat. (2011) "Mengapa Pendidikan Karakter?". Jurnal Pendidikan Karakter, Tahun I, Nomor 1, Oktober 2011. https://doi.org/10.21831/jpk.v1i1.1316

Suparlan, Henricus. (2015). "Filsafat Pendidikan Ki Hadjar Dewantara Dan Sumbangannya Bagi Pendidikan 
Indonesia". Jurnal Filsafat, Vol. 25, No.

1 ,

Februari

2015.

https://doi.org/10.22146/jf.12614 